\title{
The Candida Pathogenic Species Complex
}

\author{
Siobhán A. Turner and Geraldine Butler \\ School of Biomolecular and Biomedical Science, Conway Institute, University College Dublin, \\ Belfield, Dublin 4, Ireland \\ Correspondence: geraldine.butler@ucd.ie
}

Candida species are the most common causes of fungal infection. Approximately $90 \%$ of infections are caused by five species: Candida albicans, Candida glabrata, Candida tropicalis, Candida parapsilosis, and Candida krusei. Three (C. albicans, C. tropicalis, and C. parapsilosis) belong to the CTG clade, in which the CTG codon is translated as serine and not leucine. C. albicans remains the most commonly isolated but is decreasing relative to the other species. The increasing incidence of $C$. glabrata is related to its reduced susceptibility to azole drugs. Genome analysis suggests that virulence in the CTG clade is associated with expansion of gene families, particularly of cell wall genes. Similar independent processes took place in the $C$. glabrata species group. Gene loss and expansion in an ancestor of C. glabrata may have resulted in preadaptations that enabled pathogenicity.

$C$ andida species are among the most common human fungal pathogens and are responsible for both superficial (mucosal and cutaneous) and systemic infection (reviewed in Papon et al. 2013a). Approximately 8\% of nosocomial bloodstream infections are caused by Candida species (Pfaller and Diekema 2007). Several international surveys have tracked the incidence of Candida infection and the rates of drug resistance over the past decades (Pfaller et al. 2001, 2002, 2008, 2010a,b,c,d, 2011a,b). One of the most comprehensive studies (ARTEMIS), using data from 142 institutions in 41 countries, identified 31 species of Candida in clinical samples over a 10-year period (19972007) (Pfaller et al. 2010b). Five species are responsible for just over $92 \%$ of cases, and 13 species were very rarely identified (incidences of $<0.01 \%$ ) (Pfaller et al. 2010b). The incidence of some of the intermediate species may also be overestimated. For example, many isolates originally identified as Candida famata (Debaryomyces hansenii) were subsequently shown to be predominantly Candida guilliermondii or Candida parapsilosis (Castanheira et al. 2013).

The five species most commonly associated with candidiasis are Candida albicans (65.3\%), Candida glabrata (11.3\%), Candida tropicalis (7.2\%), C. parapsilosis (6.0\%), and Candida krusei (2.4\%) (Table 1) (Pfaller et al. 2010b). The number of infections is rising, although there was a slight drop between 2005 and 2007. C. albicans remains the most commonly isolated, but the proportion relative to other Candida species has decreased over time (from $71 \%$ to $65 \%$ ). This was accompanied by an increasing incidence of C. glabrata, C. tropicalis, and C. parapsilosis.

Editors: Arturo Casadevall, Aaron P. Mitchell, Judith Berman, Kyung J. Kwon-Chung, John R. Perfect, and Joseph Heitman Additional Perspectives on Human Fungal Pathogens available at www.perspectivesinmedicine.org

Copyright (C) 2014 Cold Spring Harbor Laboratory Press; all rights reserved; doi: 10.1101/cshperspect.a019778 Cite this article as Cold Spring Harb Perspect Med 2014;4:a019778 
S.A. Turner and G. Butler

Table 1. Candida pathogenic species

\begin{tabular}{|c|c|c|c|c|}
\hline Name $^{a}$ & Common teleomorphs/synonyms & Ploidy ${ }^{b}$ & Mating ${ }^{\mathrm{c}}$ & Incidence $^{\mathrm{d}}(\%)$ \\
\hline \multicolumn{5}{|l|}{ CTG clade species } \\
\hline C. albicans & & Diploid & $\mathrm{P}$ & 65.3 \\
\hline C. dubliniensis & & Diploid & $\mathrm{P}$ & 0.1 \\
\hline C. tropicalis & & Diploid & $\mathrm{P}$ & 7.20 \\
\hline C. parapsilosis & & Diploid & $\mathrm{NO}$ & 6.00 \\
\hline C. orthopsilosis & & Diploid & $\mathrm{NO}$ & $0.50^{\mathrm{e}}$ \\
\hline C. metapsilosis & & Diploid & NO & $<0.1^{\mathrm{e}}$ \\
\hline C. famata & Debaryomyces hansenii & Haploid & Ho & 0.30 \\
\hline C. lusitaniae & Clavispora lusitaniae & Haploid & Het & 0.60 \\
\hline C. guilliermondii & $\begin{array}{l}\text { Meyerozyma guilliermondii; Pichia } \\
\text { guilliermondii }\end{array}$ & Haploid & Het & 0.70 \\
\hline \multicolumn{5}{|l|}{ Other species } \\
\hline C. krusei & Issatchenkia orientalis; Pichia kudriavzevii & Haploid & Het & 2.40 \\
\hline C. glabrata & & Haploid & $\mathrm{NO}$ & 11.30 \\
\hline C. kefyr & Kluyveromyces marxianus & Haploid & Ho & 0.50 \\
\hline C. norvegensis & Pichia norvegensis & & Ho & 0.10 \\
\hline C. inconspicua & Pichia cactophila & & ND & 0.20 \\
\hline C. lipolytica & Yarrowia lipolytica & Haploid & Het & 0.05 \\
\hline
\end{tabular}

${ }^{\mathrm{a}}$ Species are listed in approximate order of phylogenetic relationship.

${ }^{\mathrm{b}}$ Haploid indicates isolates can exist as stable haploids; diploids may also be formed.

${ }^{\mathrm{c}} \mathrm{P}$, parasexual; NO, not observed; ND, not determined; Ho, homothallic; Het, heterothallic (data from Kurtzman et al. 2011).

dAverage incidence 1997-2007 (Pfaller et al. 2010b), except for C. metapsilosis and C. orthopsilosis.

${ }^{\mathrm{e}}$ Estimated from Canton et al. 2011; C. orthopsilosis isolates are $\sim 8 \%$ and C. metapsilosis isolates are $1 \%$ of isolates identified as $C$. parapsilosis.

The incidence also varies substantially with geographical location. C. glabrata is highest in Asia-Pacific and the European Union (EU), whereas the incidence of $C$. tropicalis infection in Africa and the Middle East is approaching three times that of the EU. C. parapsilosis is highest in North America and Latin America. The increase in C. glabrata in particular is associated with reduced susceptibility to fluconazole, the most commonly used azole drug (Pfaller and Diekema 2004; Klevay et al. 2008; ChapelandLeclerc et al. 2010; Alexander et al. 2013).

Candida species have historically been associated with infection of older patients $(>64$ yr), particularly for C. glabrata (Diekema et al. 2002). In contrast, the number of infections caused by C. parapsilosis tends to be higher in infants of $<1 \mathrm{yr}$ (Diekema et al. 2002). Recent studies suggest that at least in the United States, the incidence of all Candida species among neonates is decreasing, which may be related to standardization of central line care (Fridkin et al. 2006; Chitnis et al. 2012; Cleveland et al. 2012).

\section{CLASSIFICATION OF Candida SPECIES: THE CTG CLADE AND BEYOND}

One of the difficulties in characterizing Candida species is that they do not share a single evolutionaryorigin. The term "Candida" was assigned to imperfect fungi (no clearly defined sexual cycle). Many Candida species belong to the CTG (or CUG) clade, in which the CTG codon codes for serine, rather than leucine (Table 1) (Santos et al. 1993). The CTG clade includes many of the most important pathogens (C. albicans, C. tropicalis, and C. parapsilosis) as well as rarer causes of disease (Candida dubliniensis, Candida guilliermondii, and Candida lusitaniae) (Fitzpatrick et al. 2006, 2010; Maguire et al. 2013). Some of the species are always, or mostly, diploid (Table 1).

Many of the diploid asexual Candida species undergo a parasexual cycle, mating between diploid cells of opposite mating type, followed by loss of chromosomes and reversion to diploid status (reviewed in Sherwood and Bennett 2009; Butler 2010; Heitman 2010). The parasex- 
ual cycle has been characterized in C. albicans (Bennett and Johnson 2003; Forche et al. 2008) and C. tropicalis (Porman et al. 2011), although not in C. parapsilosis (Sai et al. 2011). Recently, it has been shown that $C$. albicans cells can form stable haploids, which undergo mating and autodiploidization (Hickman et al. 2013). A full sexual cycle has been described for many of the pathogens with haploid genomes (e.g., C. lusitaniae [Reedy et al. 2009] and C. guilliermondii (Wickerham and Burton 1954]) and some of the other related rare pathogens or nonpathogens (e.g., D. hansenii [van der Walt et al. 1977]).

The gradual discovery of hidden sexual or parasexual cycles in human fungal pathogens led to the hypothesis that limiting sexual reproduction may be important for proliferation in certain niches, particularly during infection of the host (Nielsen and Heitman 2007; Heitman 2010). This is supported by observations that the parasexual cycle in C. albicans is induced during stress (Berman and Hadany 2012). The parasexual cycle results in a very high level of aneuploidy (Forche et al. 2008). Aneuploidy also frequently occurs during exposure to antifungal drugs and is likely to be an important adaptive response (Perepnikhatka et al. 1999; Selmecki et al. 2009, 2010; Huang et al. 2011; Hill et al. 2013).

The substitution of serine for leucine at CTG codons is not complete; in C. albicans and some other Candida species, it is estimated that $97 \%$ of CTG codons are translated as serine and $3 \%$ as leucine (Suzuki et al. 1997). C. albicans has a very high tolerance for misincorporation of leucine at CTG codons, which is induced by stress (Gomes et al. 2007). Misincorporation may affect the function of key signaling molecules involved in pathogenesis (Rocha et al. 2011). Misincorporation also dramatically changes the fungal cell wall, masking $\beta$-glucan, and thus interfering with host recognition (Miranda et al. 2013). Altering the genetic code may also reduce the capacity for acquisition of genes by horizontal gene transfer (HGT) (Silva et al. 2007; Fitzpatrick et al. 2008).

Two species that are major causes of infection lie outside the CTG clade: C. glabrata and
C. krusei (Fig. 1; Table 1). C. glabrata is much more closely related to Saccharomyces cerevisiae than to C. albicans (Fitzpatrick et al. 2006), and it lies within a group of species that have undergone whole-genome duplication (WGD) (Byrne and Wolfe 2007) (Fig. 1). The C. glabrata genome contains all the genes required for mating and meiosis (Wong et al. 2003), and matingtype switching has been observed (Brockert et al. 2003; Butler et al. 2004; Edskes and Wickner 2013). However, a sexual cycle has not yet been described. Recently, two pathogenic species that are closely related to C. glabrata have been identified, Candida bracarensis and Candida nivariensis (Alcoba-Florez et al. 2005; Correia et al. 2006), but these are rarely isolated (Fig. 1) (Lockhart et al. 2009).

C. krusei is less well studied than the other Candida species, particularly in relation to virulence. The teleomorph (sexually competent) form of C. krusei is known as Issatchenkia orientalis (Kurtzman et al. 2011) or Pichia kudriavzevii. Most research concentrates on its fermentation ability and potential as a producer of bioethanol (Dandi et al. 2013). The genome sequence was recently reported (Chan et al. 2012). The carriage of C. krusei in healthy individuals is usually very low, except in some populations such as Wayampi Amerindians, where it appears to originate from food or the environment (Angebault et al. 2013). The incidence of C. krusei in infection is also low, yet the organism is of considerable concern because of its relative resistance to azoles and other antifungal drugs (Drago et al. 2004; Munoz et al. 2005).

Other non-CTG clade Candida species that are minor causes of infection include Candida kefyr (Kluyveromyces marxianus) and two closely related species, Candida norvegensis (Pichia norvegensis) and Candida inconspicua (Pichia cactophila) (Pfaller et al. 2010b). C. keyfr is related to Kluyveromyces lactis and to the Saccharomyces group (Lane et al. 2011), and C. norvegensis and C. inconspicua also belong to a clade within the Saccharomycetales (Diezmann et al. 2004). Candida lipolytica (better known as Yarrowia lipolytica), a very rare cause of infection ( $\sim 0.1 \%$ of Candida infections [Pfaller et al. 
S.A. Turner and G. Butler

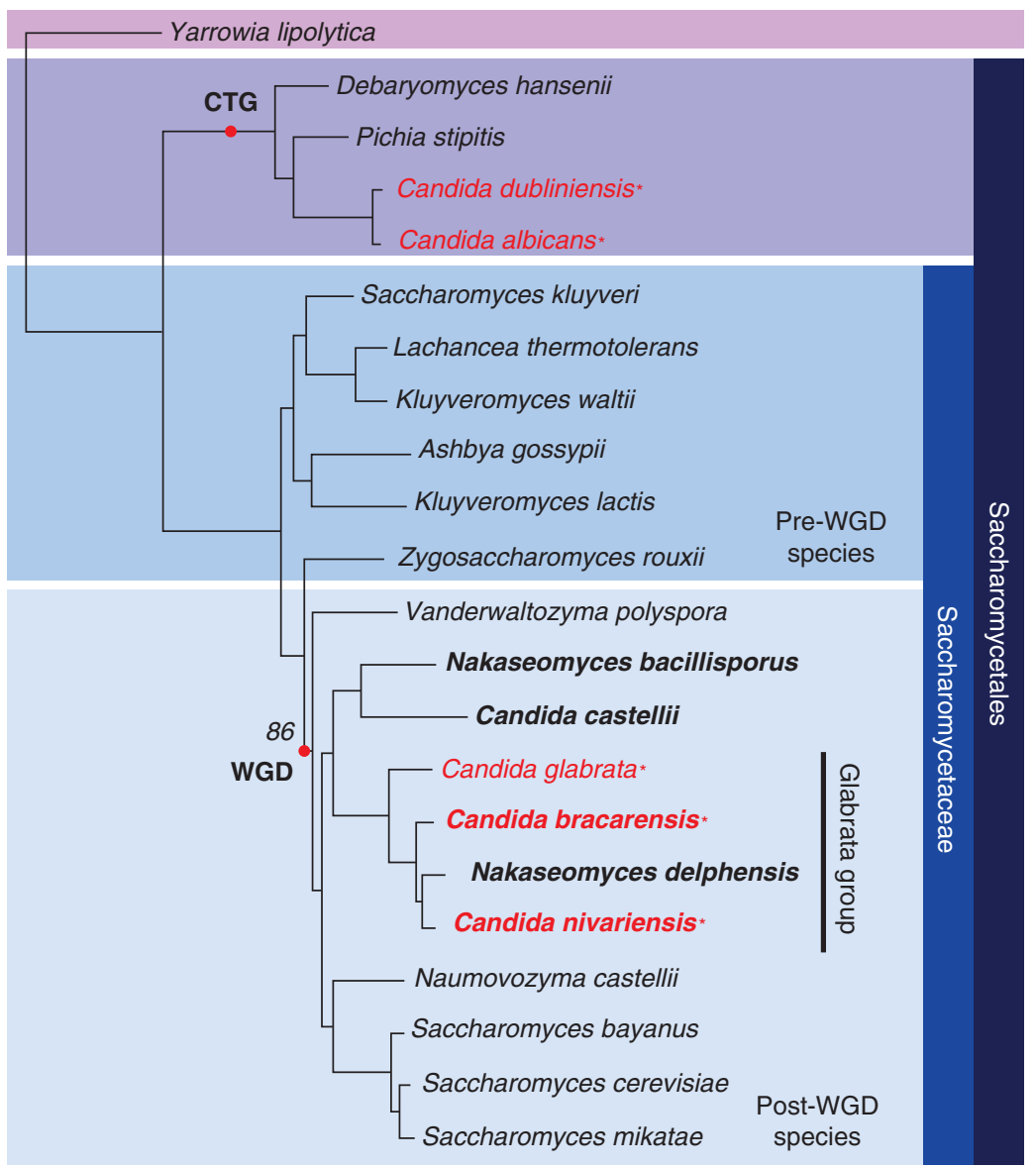

Figure 1. Relationships of the C. glabrata species group. The phylogenetic tree is taken from Gabaldón et al. (2013) and was derived from a concatenated alignment of 603 one-to-one orthologs. Genomes sequenced by Gabaldón et al. (2013) are bold. Pathogenic species are shown in red and are indicated with an asterisk. CTG, CTG clade; WGD, whole-genome duplication.

2010b]), is distantly related to both the CTG and Saccharomyces clades (Fig. 1) (Fitzpatrick et al. 2006). The remaining non-CTG clade species (e.g., Candida pelliculosa/Pichia anomola) are even rarer (Pfaller et al. 2010b).

\section{LESSONS FROM THE GENOMES}

\section{C. albicans}

C. albicans is by far the best-studied species in the CTG clade. Virulence is associated with the transition from yeast growth to filamentous forms such as hyphae and pseudohyphae (reviewed in Liu 2001; Jacobsen et al. 2012) and also with a phenotypic switch from "white" to "opaque" cells (reviewed in Morschhauser 2010; Huang 2012). Although there is some debate about the relative roles of hyphae and yeast cells in pathogenesis, hyphae are believed to be important because they can invade and damage both epithelial and endothelial cells and because they are required for escape from macrophages following phagocytosis (Thompson et al. 2011; Jacobsen et al. 2012). In addition, a large-scale screen confirmed that many genes required for virulence have no apparent role in morphogenesis and showed that others that are required for morphogenesis have no effect on virulence (Noble et al. 2010). 
The switch from round white cells to elongated opaque cells (and vice versa) is strongly correlated with mating (Bennett and Johnson 2005; Lohse and Johnson 2009). Cells that are homozygous at the mating locus switch to the opaque form at a much higher rate than heterozygous cells, and opaque cells are competent for mating. The switching process is highly regulated (Huang et al. 2006; Srikantha et al. 2006; Zordan et al. 2006, 2007; Tuch et al. 2010; Hernday et al. 2013). White and opaque cells have different filamentation programs ( $\mathrm{Si}$ et al. 2013). White cells are more virulent in systemic infection, whereas opaque cells adhere better to skin (Kvaal et al. 1997, 1999). Opaque cells may be better at evading the host immune response (Geiger et al. 2004; Sasse et al. 2013). The demonstration that strains that are heterozygous at the mating locus can also undergo the white-opaque transition in certain environmental conditions suggests that the switch may be important for virulence of many clinical isolates (Xie et al. 2013).

The genome sequence of $C$. albicans was first reported in 2004 (Jones et al. 2004) and further curated in 2005 (Braun et al. 2005). Assembly of the diploid genome was partially addressed in 2007 (van het Hoog et al. 2007), and a "phased" diploid genome was reported in 2013 (Muzzey et al. 2013). C. albicans SC5314 plus eight related strains, which were known to be homozygous for one chromosome each, were sequenced using high-coverage next-generation sequencing. This enabled unambiguous determination of the phasing of single-nucleotide polymorphisms (SNPs) in the parent strain. The analyses supported previous observations from SNP/CGH arrays that loss of heterozygosity $(\mathrm{LOH})$ events are common in C. albicans (Abbey et al. 2011). Indeed, LOH is induced by stress such as exposure to antifungal drugs or growth in a mammalian host (Forche et al. 2009, 2011). However, some chromosomes or chromosomal regions are never observed to become homozygous, probably because they contain lethal alleles (Hickman et al. 2013).

Allele-specific gene expression was detected even in C. albicans grown in rich media (Muzzey et al. 2013). Almost 200 genes have premature termination codons in one allele, and in the majority, expression is biased toward the intact allele. Muzzey et al. (2013) found that indels are enriched in regulatory (promoter) regions, although there was no obvious correlation with allele-specific gene expression. Interestingly, the net effect of indels is to increase repeat length over evolutionary time, which may result from selective forces on nucleosome positioning.

Early comparisons of the C. albicans genome with that of the nonpathogenic model yeast $S$. cerevisiae led to the identification of several gene families that are expanded in the pathogen and are associated with virulence (Calderone and Fonzi 2001; Jones et al. 2004; Braun et al. 2005). These include the ALS (agglutinin-like sequence) adhesins, secreted aspartyl proteases and lipases, and proteins involved in oligopeptide and iron transfer. Subsequent analysis showed that many gene families are expanded in other species in the CTG clade (Butler et al. 2009). Twenty-one gene families are enriched in the pathogens.

The ALS family of adhesins is expanded in all the CTG pathogens, and its members have been particularly associated with virulence in C. albicans (Hoyer 2001; Hoyer et al. 2008). ALS genes encode GPI-anchored proteins located at the cell wall and are required for adhesion. ALS3 in particular has multiple roles. It is required for adherence to plastic and for subsequent biofilm development (Nobile and Mitchell 2005; Nobile et al. 2006). Als3 binds to $\mathrm{N}$-cadherin and E-cadherin on host endothelial and epithelial cells and, together with the invasion Ssa1, is required for endocytosis of $C$. albicans (Phan et al. 2007; Moreno-Ruiz et al. 2009; Wachtler et al. 2012). Als3 and Ssa1 also bind to the EGF (epidermal growth factor) receptor and to HER2 in epithelial cells, inducing autophosphorylation of the receptors and endocytosis of the fungus (Zhu et al. 2012). Finally, Als3 is required for acquisition of iron from ferritin in the host (Almeida et al. 2008).

Somewhat surprisingly, Als3 appears to be restricted to C. albicans (Jackson et al. 2009), which may partially explain the dominance of C. albicans as an infectious organism. Recom- 
binant vaccines directed against $C$. albicans have mostly been generated using the amino terminus of Als3 (Spellberg et al. 2006; Ibrahim et al. 2013). However, the vaccine is also protective against infection with Staphylococcus aureus, suggesting that it has a broad range (Spellberg et al. 2008).

Many of the gene families that are expanded in pathogenic species encode components of the cell wall, which may influence interaction with the host (Butler et al. 2009). Some have been experimentally associated with pathogenesis such as the Hyr/IFF family (Bates et al. 2007; Kempf et al. 2009). However, other families, such as the leucine-rich IFA family of putative transmembrane proteins, remain understudied.

To date, most characterizations of C. albicans isolates have been carried out using molecular fingerprinting methods, such as the Ca3 fingerprinting probe, multilocus sequence typing (MLST), multilocus microsatellite typing (MLMT), and SNP array analysis (Soll 2000; Bougnoux et al. 2002; Odds 2010; L'Ollivier et al. 2012). MLST is probably the most widely applied and has been used to type $>2000 C$. albicans isolates (Bougnoux et al. 2002, 2008; Odds et al. 2007; Odds 2010; Butler et al. 2012). The population structure is mostly clonal, with the majority of isolates falling into five major clades and more than 10 minor clades (Odds et al. 2007; Odds 2010). A small number of "atypical" isolates, mostly isolated from the genitals of Africans and Europeans, fall into MLST clade 13, which is the most different from the other clades (Odds 2010; Butler et al. 2012). There is evidence that there is a low level of recombination within and between the clades (Bougnoux et al. 2008).

The majority of isolates associated with superficial infection and commensal carriage fall into Clade 1 and have a truly global distribution, suggesting that they may be better adapted for colonization (Schmid et al. 1999; Odds et al. 2007; Odds 2010). However, isolates from the different clades do not differ in virulence in animal models (MacCallum et al. 2009). Clade 1 isolates are generally resistant to the antifungal drug flucytosine (a fluorinated analog of cytosine), because of a mutation in the FUR1 gene (uridine phosphoribosyl transferase) (Dodgson et al. 2004). Clade 1 isolates are also resistant to terbinafine (Odds 2009). Few other traits are clade specific, and there is a wide variation in the phenotypes of the individual isolates (MacCallum et al. 2009).

Molecular typing methods have been used to type microevolution events during infection, to follow the transition from commensal to infectious organism, and to look for evidence of nosocomial transmission (Odds 2010). However, it is not possible to distinguish between closely related isolates, nor to follow small changes that occur during infection. In the near future, we expect to see whole-genome sequencing replacing MLST analysis, both for population studies and for following the course of infection.

\section{C. albicans and C. dubliniensis}

C. dubliniensis is the closest relative of C. albicans with a fully sequenced genome, and until the mid-1990s, it was not recognized as a distinct species (Sullivan et al. 1995). However, C. dubliniensis is a rare cause of disease in man and is also less virulent in animal models (Gilfillan et al. 1998; Stokes et al. 2007; Pfaller et al. 2010b). Comparison of the genomes of the two species revealed that there has been widespread gene loss in C. dubliniensis. Some genes have been deleted, such as members of the serine protease SAP family and HYR1 (one of the IFF gene family). Others have undergone pseudogenization, including many of the filamentous gene regulator (FGR) family. In contrast, some genes have been specifically amplified in C. albicans, such as the TLO family, which encode components of the mediator complex (Zhang et al. 2012a).

Several of the genomic differences between C. albicans and C. dubliniensis are related to the ability to switch to hyphal growth. Within the CTG clade, only C. albicans and C. dubliniensis form true hyphae. However, the conditions that induce hyphal growth are significantly different, and C. dubliniensis makes much fewer hyphae. It is very likely that this is caused by underlying 
The Candida Pathogenic Species Complex

differences in transcriptional networks as well as in genome content. This question was thoroughly addressed by Grumaz et al (2013), who characterized the transcriptional profile of both species during the yeast to hyphal transition. They found that there is a shared core hyphal response, which includes increased expression of cell wall genes and of genes associated with iron metabolism. Expression of the transcription factors FCR1, NRG1, and RME1 is reduced in both species. However, under some conditions, such as following phagocytosis by macrophages, NRG1 is down-regulated in C. albicans and not in $C$. dubliniensis, at least partly explaining inefficient hyphal production by the latter (Moran et al. 2007).

Grumaz et al. (2013) found that expression of the regulators UME6, SFL2, SET3, and ZCF39 is induced during hyphal growth of $C$. albicans only. However, other studies showed that UME6 is also induced in hyphal growth of C. dubliniensis Wu284 (O'Connor et al. 2010). Specific repression of SFL2 in C. albicans was identified by Spiering et al. (2010). SFL2 is a major regulator of morphogenesis in C. albicans and acts together with a homolog SFL1 to regulate expression of hyphal- and yeast-specific genes (Znaidi et al. 2013).

Further comparative transcriptional profiling of C. albicans and C. dubliniensis is likely to yield further insights into the evolution of virulence and other characteristics. For example, these are the only CTG clade species known to form chlamydospores (large, thick-walled spherical cells, usually found at the end of pseudohyphae) under certain growth conditions. The biological function of chlamydospores is not known, but production is induced in nutrient-poor media and in $n r g 1$ deletion strains in C. albicans, and during growth of C. dubliniensis on Staib media (reviewed in Staib and Morschhauser 2007). Comparing the transcriptional response of the two species revealed that at least two cell wall proteins (CSP1 and CSP2) are specifically expressed and localized in chlamydospores in both (Palige et al. 2013). Future research is needed to elucidate the biological role of this unusual morphogenic pathway.

\section{C. tropicalis and C. parapsilosis}

C. tropicalis is a common cause of infection in intensive care units and is a particular problem in neutropenic patients (Negri et al. 2012; Silva et al. 2012). The organism has a diploid genome and, like C. albicans, has a parasexual cycle (Porman et al. 2011; Seervai et al. 2013). In addition, $C$. tropicalis switches from white to opaque cells (Porman et al. 2013; Xie et al. 2013). However, there are also significant differences between the species. White-opaque switching in C. tropicalis is independent of mating type, whereas in C. albicans, isolates that are heterozygous at the mating locus only switch in very defined conditions (Xie et al. 2012; Porman et al. 2013). The Wor 1 transcription factor regulates the white-opaque switch in both species, but other transcription factors appear to be specific to C. albicans (Porman et al. 2011, 2013). The role of the white-opaque switch in determining virulence of $C$. tropicalis is not yet known.

C. parapsilosis is particularly associated with infection of neonates (Chow et al. 2012; Pammi et al. 2013). Drug resistance is a problem; isolates are inherently less susceptible to echinocandins because of amino acid substitutions in the $\beta$-(1,3)-D-glucan synthase FKS gene (Garcia-Effron et al. 2008). The species is more distantly related to $C$. albicans than is either $C$. dubliniensis or C. tropicalis (Fitzpatrick et al. 2006). Close relatives include C. orthopsilosis and $C$. metapsilosis, once characterized as belonging to the same species (Tavanti et al. 2005). C. orthopsilosis and C. metapsilosis are much less frequent causes of infection than C. parapsilosis (Table 1) and are less virulent in animal models (Nemeth et al. 2013). Comparing the genomes of $C$. parapsilosis and $C$. orthopsilosis suggests that amplification of gene families, in particular of cell wall genes, is associated with increased virulence of C. parapsilosis (Riccombeni et al. 2012).

C. parapsilosis has a diploid genome, but the level of heterozygosity is much lower than the other diploid CTG species (Butler et al. 2009). All isolates characterized to date have MTLa idiomorphs at the mating-type locus, and mat- 
ing has not been observed in either C. parapsilosis or C. orthopsilosis (Sai et al. 2011). Some characteristics, such as secretion of lipases, are important for virulence in both $C$. albicans and C. parapsilosis (Trofa et al. 2011). There are, however, other species-specific traits. Biofilm formation is an important for virulence in both, and the Bcrl transcription factor is a major regulator (Nobile et al. 2006; Ding and Butler 2007). However, the functions and/ or targets may be different; whereas Bcr1 regulates expression of the CFEM cell wall family in both species, the family is required for biofilm development only in C. albicans (Ding et al. 2011).

White-opaque switching has not been observed in C. parapsilosis isolates. However, colonies do undergo several types of morphological switching (Lott et al. 1993; Laffey and Butler 2005; Kim et al. 2006). The transcription factor Efg1 is a major regulator of switching from concentric to smooth colonies, and the switching rate is dramatically increased when EFG1 is deleted (Connolly et al. 2013). Efg1 regulates filamentation, white-opaque switching, and many other phenotypes in C. albicans (reviewed in Liu 2002). Many of the targets are shared in C. parapsilosis, suggesting that Efg1 is an ancient regulator of morphology (Connolly et al. 2013). Notably, however, EFG1 is missing from $C$. tropicalis (Fig. 2) (Porman et al. 2011). A second transcription factor, UME6, is required for filamentation ( pseudohyphal growth) in C.parapsilosis, C. tropicalis, and C. guilliermondii, indicating that it is also a core regulator of morphology in the CTG clade (Lackey et al. 2013).

\section{OTHER CTG CLADE SPECIES}

C. guilliermondii and C. lusitaniae are relatively rare causes of human infection. C. guilliermon$\mathrm{dii}$ is of general interest to the biotechnology sector, as a producer both of riboflavin and of xylitol (Papon et al. 2013b), and several molecular tools have been developed (Papon et al. 2012). The species is haploid and fully sexual, which may facilitate genetic analysis. Resistance to antifungal drugs is a growing problem (Savini et al. 2011).
C. lusitaniae has historically been associated with reduced susceptibility to amphotericin B, which may be related to altered expression of ergosterol synthesis genes (Merz 1984; Hadfield et al. 1987; Young et al. 2003). However, azole therapies are effective (Hawkins and Baddour 2003). C. lusitaniae isolates are haploid and heterothallic; the mating pathway has been characterized (Reedy et al. 2009), and gene disruption tools have been developed (El-Kirat-Chatel et al. 2011; Zhang et al. 2012b). Molecular characterization is therefore likely to increase in the near future.

\section{The C. glabrata Species Group}

C. glabrata is one of only two of the major Candida pathogens that falls outside of the CTG clade. The species is a common cause of candidiasis in immunosuppressed patients including those suffering from HIV/AIDS, diabetes, cancer patients undergoing chemotherapy, and the elderly (Fidel et al. 1999). C. glabrata-associated candidiasis largely occurs in the oral cavity, and its incidence in older members of the population has been linked to its ability to attach to the acrylic surface of dentures as well as increased suppression of the immune response (Lockhart et al. 1999; Bagg et al. 2003; Li et al. 2007).

Increasing incidence of C. glabrata infection also results from the increased use of prophylactic antifungal treatment in immunosuppressed patients (Chakrabarti et al. 2009; Lee et al. 2009). C. glabrata exhibits low-level resistance to the antifungal agent fluconazole; prophylactic exposure to fluconazole can induce resistance, as well as lead to cross-resistance to other related azoles (Panackal et al. 2006). Most resistant isolates have gain-of-function mutations in the PDR1 transcription factor, which regulates expression of the multidrug transporters' CDR genes (Vermitsky and Edlind 2004; Tsai et al. 2006; Vermitsky et al. 2006). PDR1 is also required for adherence and for virulence (Ferrari et al. 2011; Vale-Silva et al. 2013). Resistance to echinocandins is associated with mutations in the FKS1 and FKS2 genes (Garcia-Effron et al. 2009; Alexander et al. 2013). 


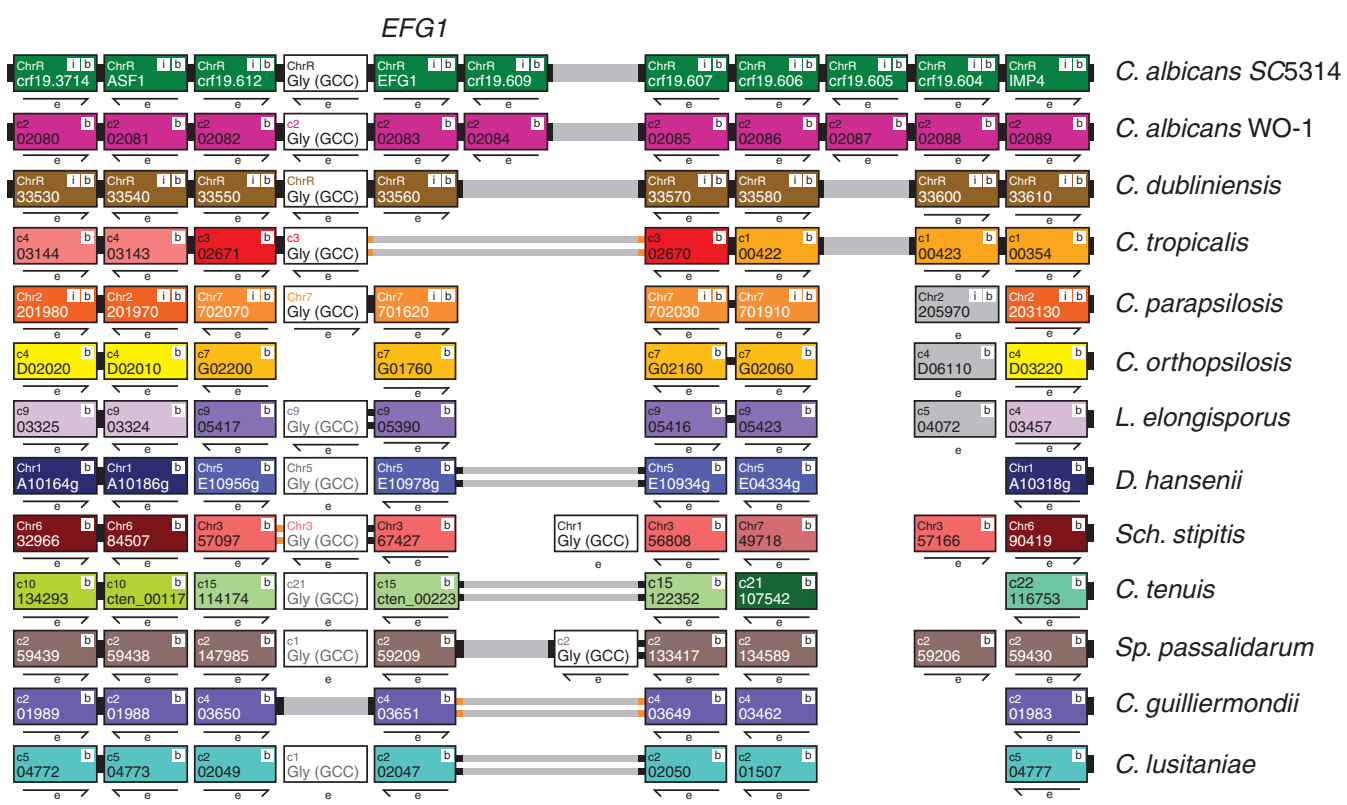

Figure 2. Visualization of EFG1 orthologs in the Candida Gene Order Browser. The diagram shows a screenshot from CGOB (cgob.ucd.ie; Fitzpatrick et al. 2010; Maguire et al. 2013) around the EFG1 gene in CTG clade species. Each horizontal line shows a chromosomal region, and each pillar indicates orthologs. All genes are shown at the same size. Breaks in synteny are indicated by changes in color. EFG1 lies between a tRNA gene (white) and orthologs of orf19.607 in most species (C. albicans isolates have an additional gene). In C. tropicalis, there has been an inversion adjacent to the tRNA relative to $C$. albicans (indicated by gray lines with orange tips), and EFG1 has been lost.

Sequencing the C. glabrata genome in 2004 revealed that there was widespread gene loss relative to $S$. cerevisiae, including the galactose, phosphate, and nicotinic acid metabolism (BNA) pathways (Dujon et al. 2004). There was also a significant expansion of the EPA family of glycolipid proteins and of the YPS family of GPI-linked aspartyl proteases, which are required for virulence (De Las Penas et al. 2003; Kaur et al. 2007). Expression of the subtelomeric EPA adhesins is usually silenced, except during infection of the urinary tract (Domergue et al. 2005). Limitation of nicotinic acid in urine (and lack of the BNA pathway) leads to a reduction in $\mathrm{NAD}^{+}$, required for activity of the histone deacetylase Sir2. The resulting change in chromatin structure induces expression of the EPA genes, leading to increased adherence.

The evolution of pathogenicity in C. glabrata is of particular interest because, until recently, it was believed to be the only pathogenic yeast species belonging to the WGD group of the Saccharomycetaceae (Fig. 1). It has now, however, been joined by $C$. bracarensis and $C$. nivariensis (Alcoba-Florez et al. 2005; Correia et al. 2006). Gabaldón et al. (2013) recently sequenced the genomes of $C$. bracarensis and $C$. nivariensis and of three related but nonpathogenic species, Nakaseomyces bacillisporus, Candida castellii, and Nakaseomyces delphensis (Fig. 1). Interestingly, C. bracarensis and C. nivariensis are more closely related to the nonpathogenic $N$. delphensis than they are to C. glabrata. N. bacillisporus and C. castellii form a separate and more distantly related group (Fig. 1).

One of the first observations was that loss of the nicotinic acid pathway is common to all of the sequenced genomes and is not unique to C. glabrata, as previously assumed (Domergue et al. 2005). This is also true for the galactose, phosphate, and other gene clusters. In addition, there is evidence for accelerated evolution in 
the lineage leading to the glabrata group (the three pathogens plus $N$. delphensis). Gabaldón et al. (2013) suggested that some of these changes may be "preadaptations" that enabled pathogenicity, rather than direct adaptations to the human host. These findings highlight the importance of sequencing the genomes of multiple species to avoid erroneous conclusions from, for example, simply comparing C. glabrata to $S$. cerevisiae.

Expansion of the EPA genes is mostly restricted to the pathogens and appears to have occurred in a lineage-specific manner. C. bracarensis and C. nivariensis share many EPA duplications, suggesting they may have occurred in the common ancestor and were subsequently lost (or possibly pseudogenized) in the nonpathogen $N$. delphensis. Amplification in $C$. glabrata occurred independently. Correlation of EPA expansion with pathogenesis and the observation that they are required for adherence in C. glabrata suggest that this family is important for virulence. The C. glabrata genome also has expanded YPS and MNT3 arrays, predicted to be involved in carbohydrate metabolism. It is therefore likely that C. glabrata has undergone species-specific gene amplification, which may explain why it is significantly more virulent than the other pathogenic species within the Nakaseomyces group.

One difficulty with this analysis is the definition of pathogenesis: C. bracarensis and $C$. nivariensis are rare, but their emergence is likely a result of improved detection methods due to sequence analysis. Another important factor is opportunity. Species defined as nonpathogenic, because they are not isolated from clinical settings, may cause infection if they came into contact with a human host. Interpretations may also change as additional genomes are sequenced. Gabaldón et al. (2013) postulated that the Nakaseomyces group evolved from an ancestral environmental yeast; gene loss and amplifications enabled growth as commensals in humans, and some species independently evolved into opportunistic pathogens. Similar to yeasts of the CTG clade, the evolution of pathogenicity is associated with changes in genes involved in cell adhesion, carbohydrate metabolism, the hypoxic response, and phosphate starvation, enhancing the ability of the yeasts to survive in the host environment.

\section{CONCLUDING REMARKS: THE FUTURE OF GENOMICS IN Candida}

Improvements in genome sequencing have been paralleled by improvements in genome annotation, particularly for C. albicans and other species in the CTG clade. Use of RNA-seq and highresolution tiling arrays has led to the correction of many open reading frames (ORFs) and the identification of hundreds of novel transcriptionally active regions that may represent structural or regulatory RNAs (Bruno et al. 2010; Sellam et al. 2010; Tuch et al. 2010). Strandspecific RNA sequencing has revealed that the $5^{\prime}$ end of transcripts that are differentially expressed between white and opaque cells are particularly long (Tuch et al. 2010). RNA-seq data has provided experimental evidence for the presence of introns and identified several that had not been predicted computationally ( $\mathrm{Mi}-$ trovich et al. 2007).

RNA-seq analysis has also been important for annotation of other genomes, such as $C$. parapsilosis (Guida et al. 2011) and C. dubliniensis (Grumaz et al. 2013). In C. parapsilosis, several hundred new genes were identified, and approximately 900 gene models were corrected (Guida et al. 2011). It is becoming increasingly clear that the high level of unknown transcripts, or even antisense transcripts, in Candida species is indicative of a layer of regulation that is at present almost completely unexplored and is likely to be an important focus in the future. Even in the absence of transcriptional data, however, comparative genomics applications are very useful for identifying protein-coding regions. For example, comparing the genomes of six species in the CTG clade led to the identification of 91 novel ORFs in C. albicans (Butler et al. 2009). A more detailed analysis uncovered more than 1500 previously unannotated ORFs in 13 genomes (Maguire et al. 2013) (Fig. 2).

Tools pioneered in $S$. cerevisiae are now being applied to C. albicans and hopefully to other Candida species also. Several collections of gene 
The Candida Pathogenic Species Complex

disruptions and gene knockouts have been generated in C. albicans and, together with gene expression profiling and chromatin immunoprecipitation, have been applied to identifying networks involved in adhesion, biofilm formation, virulence, and more (Chen et al. 2011; Finkel et al. 2012; Nobile et al. 2012; Pande et al. 2013; Perez et al. 2013). The developments of an overexpression library and constitutively activated transcription factors are also exciting (Chauvel et al. 2012; Schillig and Morschhauser 2013). Characterization of stable haploids of C. albicans will open up huge new areas of research and may allow the application of methods such as synthetic genetic arrays, although a meiotic cycle is required to fully exploit these approaches (Baryshnikova et al. 2010). We will no doubt see a major increase in sequencing individual isolates from a single species, which will facilitate analysis of clade-specific traits (Engel and Cherry 2013). The future will bring an explosion in data availability, and the challenges that come with dealing with it.

\section{ACKNOWLEDGMENTS}

Work in the Butler lab is supported by Science Foundation Ireland and the Wellcome Trust. The contributions of several laboratory members are appreciated.

\section{REFERENCES}

Abbey D, Hickman M, Gresham D, Berman J. 2011. Highresolution SNP/CGH microarrays reveal the accumulation of loss of heterozygosity in commonly used Candida albicans strains. G3 (Bethesda) 1: 523-530.

Alcoba-Florez J, Mendez-Alvarez S, Cano J, Guarro J, PerezRoth E, del Pilar Arevalo M. 2005. Phenotypic and molecular characterization of Candida nivariensis sp. nov., a possible new opportunistic fungus. J Clin Microbiol 43: 4107-4111.

Alexander BD, Johnson MD, Pfeiffer CD, Jimenez-Ortigosa C, Catania J, Booker R, Castanheira M, Messer SA, Perlin DS, Pfaller MA. 2013. Increasing echinocandin resistance in Candida glabrata: Clinical failure correlates with presence of FKS mutations and elevated minimum inhibitory concentrations. Clin Infect Dis 56: 1724-1732.

Almeida RS, Brunke S, Albrecht A, Thewes S, Laue M, Edwards JE, Filler SG, Hube B. 2008. The hyphal-associated adhesin and invasin Als3 of Candida albicans mediates iron acquisition from host ferritin. PLoS Pathog 4: e1000217.
Angebault C, Djossou F, Abelanet S, Permal E, Ben Soltana M, Diancourt L, Bouchier C, Woerther PL, Catzeflis F, Andremont A, et al. 2013. Candida albicans is not always the preferential yeast colonizing humans: A study in Wayampi Amerindians. J Infect Dis 208: 1705-1716.

Bagg J, Sweeney MP, Lewis MA, Jackson MS, Coleman D, Al MA, Baxter W, McEndrick S, McHugh S. 2003. High prevalence of non-albicans yeasts and detection of antifungal resistance in the oral flora of patients with advanced cancer. Palliat Med 17: 477-481.

Baryshnikova A, Costanzo M, Dixon S, Vizeacoumar FJ, Myers CL, Andrews B, Boone C. 2010. Synthetic genetic array (SGA) analysis in Saccharomyces cerevisiae and Schizosaccharomyces pombe. Methods Enzymol 470: 145-179.

Bates S, de la Rosa JM, MacCallum DM, Brown AJ, Gow NA, Odds FC. 2007. Candida albicans Iff11, a secreted protein required for cell wall structure and virulence. Infect Immun 75: 2922-2928.

Bennett RJ, Johnson AD. 2003. Completion of a parasexual cycle in Candida albicans by induced chromosome loss in tetraploid strains. EMBO J 22: 2505-2515.

Bennett RJ, Johnson AD. 2005. Mating in Candida albicans and the search for a sexual cycle. Annu Rev Microbiol 59: 233-255.

Berman J, Hadany L. 2012. Does stress induce (para)sex? Implications for Candida albicans evolution. Trends Genet 28: 197-203.

Bougnoux ME, Morand S, d'Enfert C. 2002. Usefulness of multilocus sequence typing for characterization of clinical isolates of Candida albicans. J Clin Microbiol 40: 1290-1297.

Bougnoux ME, Pujol C, Diogo D, Bouchier C, Soll DR, d'Enfert C. 2008. Mating is rare within as well as between clades of the human pathogen Candida albicans. Fungal Genet Biol 45: 221-231.

Braun BR, van Het Hoog M, d'Enfert C, Martchenko M, Dungan J, Kuo A, Inglis DO, Uhl MA, Hogues H, Berriman M, et al. 2005. A human-curated annotation of the Candida albicans genome. PLoS Genet 1: e1.

Brockert PJ, Lachke SA, Srikantha T, Pujol C, Galask R, Soll DR. 2003. Phenotypic switching and mating type switching of Candida glabrata at sites of colonization. Infect Immun 71: 7109-7118.

Bruno VM, Wang Z, Marjani SL, Euskirchen GM, Martin J, Sherlock G, Snyder M. 2010. Comprehensive annotation of the transcriptome of the human fungal pathogen Candida albicans using RNA-seq. Genome Res 20: 14511458.

Butler G. 2010. Fungal sex and pathogenesis. Clin Microbiol Rev 23: $140-159$.

Butler G, Kenny C, Fagan A, Kurischko C, Gaillardin C, Wolfe KH. 2004. Evolution of the MAT locus and its Ho endonuclease in yeast species. Proc Natl Acad Sci 101: $1632-1637$.

Butler G, Rasmussen MD, Lin MF, Santos MA, Sakthikumar S, Munro CA, Rheinbay E, Grabherr M, Forche A, Reedy JL, et al. 2009. Evolution of pathogenicity and sexual reproduction in eight Candida genomes. Nature 459: $657-662$. 
Butler G, Lorenz M, Gow NAR. 2012. Evolution and genomics of the pathogenic Candida species complex. In Evolution of virulence in eukaryotic microbes (ed. Sibley DL, Howlett BJ, Heitman J), pp. 404-421. Wiley-Blackwell, Hoboken, NJ.

Byrne KP, Wolfe KH. 2007. Consistent patterns of rate asymmetry and gene loss indicate widespread neofunctionalization of yeast genes after whole-genome duplication. Genetics 175: 1341-1350.

Calderone RA, Fonzi WA. 2001. Virulence factors of Candida albicans. Trends Microbiol 9: 327-335.

Canton E, Peman J, Quindos G, Eraso E, Miranda-Zapico I, Alvarez M, Merino P, Campos-Herrero I, Marco F, de la Pedrosa EG, et al. 2011. Prospective multicenter study of the epidemiology, molecular identification, and antifungal suscepibility of Candida parapsilosis, Candida orthopsilosis, and Candida metapsilosis isolated from patients with candidemia. Antimicrob Agents chemother 55: 5590-5596.

Castanheira M, Woosley LN, Diekema DJ, Jones RN, Pfaller MA. 2013. Candida guilliermondii and other species of Candida misidentified as Candida famata: Assessment by vitek 2, DNA sequencing analysis, and matrix-assisted laser desorption ionization-Time of flight mass spectrometry in two global antifungal surveillance programs. J Clin Microbiol 51: 117-124.

Chakrabarti A, Chatterjee SS, Rao KL, Zameer MM, Shivaprakash MR, Singhi S, Singh R, Varma SC. 2009. Recent experience with fungaemia: Change in species distribution and azole resistance. Scand J Infect Dis 41: 275-284.

Chan GF, Gan HM, Ling HL, Rashid NA. 2012. Genome sequence of Pichia kudriavzevii M12, a potential producer of bioethanol and phytase. Eukaryot Cell 11: 1300 1301.

Chapeland-Leclerc F, Hennequin C, Papon N, Noel T, Girard A, Socie G, Ribaud P, Lacroix C. 2010. Acquisition of flucytosine, azole, and caspofungin resistance in Candida glabrata bloodstream isolates serially obtained from a hematopoietic stem cell transplant recipient. Antimicrob Agents Chemother 54: 1360-1362.

Chauvel M, Nesseir A, Cabral V, Znaidi S, Goyard S, Bachellier-Bassi S, Firon A, Legrand M, Diogo D, Naulleau C, et al. 2012. A versatile overexpression strategy in the pathogenic yeast Candida albicans: Identification of regulators of morphogenesis and fitness. PLoS ONE 7: e45912.

Chen C, Pande K, French SD, Tuch BB, Noble SM. 2011. An iron homeostasis regulatory circuit with reciprocal roles in Candida albicans commensalism and pathogenesis. Cell Host Microbe 10: 118-135.

Chitnis AS, Magill SS, Edwards JR, Chiller TM, Fridkin SK, Lessa FC. 2012. Trends in Candida central line-associated bloodstream infections among NICUs, 1999-2009. Pediatrics 130: e46-e52.

Chow BD, Linden JR, Bliss JM. 2012. Candida parapsilosis and the neonate: Epidemiology, virulence and host defense in a unique patient setting. Expert Rev Anti Infect Ther 10: 935-946.

Cleveland AA, Farley MM, Harrison LH, Stein B, Hollick R, Lockhart SR, Magill SS, Derado G, Park BJ, Chiller TM. 2012. Changes in incidence and antifungal drug resistance in candidemia: Results from population-based lab- oratory surveillance in Atlanta and Baltimore, 20082011. Clin Infect Dis 55: 1352-1361.

Connolly LA, Riccombeni A, Grozer Z, Holland LM, Lynch DB, Andes DR, Gacser A, Butler G. 2013. The APSES transcription factor Efg1 is a global regulator that controls morphogenesis and biofilm formation in Candida parapsilosis. Mol Microbiol 90: 36-53.

Correia A, Sampaio P, James S, Pais C. 2006. Candida bracarensis sp. nov., a novel anamorphic yeast species phenotypically similar to Candida glabrata. Int J Syst Evol Microbiol 56: 313-317.

Dandi ND, Dandi BN, Chaudhari AB. 2013. Bioprospecting of thermo- and osmo-tolerant fungi from mango pulppeel compost for bioethanol production. Antonie Van Leeuwenhoek 103: 723-736.

De Las Penas SJ, Castano J, Cregg R, Cormack BP. 2003. Virulence-related surface glycoproteins in the yeast pathogen Candida glabrata are encoded in subtelomeric clusters and subject to RAP1- and SIR-dependent transcriptional silencing. Genes Dev 17: 2245-2258.

Diekema DJ, Messer SA, Brueggemann AB, Coffman SL, Doern GV, Herwaldt LA, Pfaller MA. 2002. Epidemiology of candidemia: 3-Year results from the emerging infections and the epidemiology of Iowa organisms study. J Clin Microbiol 40: 1298-1302.

Diezmann S, Cox CJ, Schonian G, Vilgalys RJ, Mitchell TG. 2004. Phylogeny and evolution of medical species of Candida and related taxa: A multigenic analysis. J Clin Microbiol 42: 5624-5635.

Ding C, Butler G. 2007. Development of a gene knockout system in Candida parapsilosis reveals a conserved role for BCR1 in biofilm formation. Eukaryot Cell 6: 1310-1319.

Ding C, Vidanes GM, Maguire SL, Guida A, Synnott JM, Andes DR, Butler G. 2011. Conserved and divergent roles of Bcrl and CFEM proteins in Candida parapsilosis and Candida albicans. PLoS ONE 6: e28151.

Dodgson AR, Dodgson KJ, Pujol C, Pfaller MA, Soll DR. 2004. Clade-specific flucytosine resistance is due to a single nucleotide change in the FUR1 gene of Candida albicans. Antimicrob Agents Chemother 48: 2223-2227.

Domergue R, Castano I, De Las Penas A, Zupancic M, Lockatell V, Hebel RJ, Johnson D, Cormack BP. 2005. Nicotinic acid limitation regulates silencing of Candida adhesins during UTI. Science 308: 866-870.

Drago M, Scaltrito MM, Morace G. 2004. In vitro activity of voriconazole and other antifungal agents against clinical isolates of Candida glabrata and Candida krusei. Eur J Clin Microbiol Infect Dis 23: 619-624.

Dujon B, Sherman D, Fischer G, Durrens P, Casaregola S, Lafontaine I, De Montigny J, Marck C, Neuveglise C, Talla E, et al. 2004. Genome evolution in yeasts. Nature 430: $35-44$.

Edskes HK, Wickner RB. 2013. The [URE3] prion in Candida. Eukaryot Cell 12: 551-558

El-Kirat-Chatel S, Dementhon K, Noel T. 2011. A two-step cloning-free PCR-based method for the deletion of genes in the opportunistic pathogenic yeast Candida lusitaniae. Yeast 28: 321-330.

Engel SR, Cherry JM. 2013. The new modern era of yeast genomics: Community sequencing and the resulting annotation of multiple Saccharomyces cerevisiae strains at 
the Saccharomyces Genome Database. Database 2013: bat012.

Ferrari S, Sanguinetti M, Torelli R, Posteraro B, Sanglard D. 2011. Contribution of CgPDR1-regulated genes in enhanced virulence of azole-resistant Candida glabrata. PLOS ONE 6: e17589.

Fidel PL Jr, Vazquez JA, Sobel JD. 1999. Candida glabrata: Review of epidemiology, pathogenesis, and clinical disease with comparison to C. albicans. Clin Microbiol Rev 12: $80-96$

Finkel JS, Xu W, Huang D, Hill EM, Desai JV, Woolford CA, Nett JE, Taff H, Norice CT, Andes DR, et al. 2012. Portrait of Candida albicans adherence regulators. PLoS Pathog 8: e1002525.

Fitzpatrick DA, Logue ME, Stajich JE, Butler G. 2006. A fungal phylogeny based on 42 complete genomes derived from supertree and combined gene analysis. BMC Evol Biol 6: 99.

Fitzpatrick DA, Logue ME, Butler G. 2008. Evidence of recent interkingdom horizontal gene transfer between bacteria and Candida parapsilosis. BMC Evol Biol 8: 181.

Fitzpatrick DA, O'Gaora P, Byrne KP, Butler G. 2010. Analysis of gene evolution and metabolic pathways using the Candida Gene Order Browser. BMC Genomics 11: 290.

Forche A, Alby K, Schaefer D, Johnson AD, Berman J, Bennett RJ. 2008. The parasexual cycle in Candida albicans provides an alternative pathway to meiosis for the formation of recombinant strains. PLoS Biol 6: e110.

Forche A, Magee PT, Selmecki A, Berman J, May G. 2009. Evolution in Candida albicans populations during a single passage through a mouse host. Genetics 182: 799-811.

Forche A, Abbey D, Pisithkul T, Weinzierl MA, Ringstrom T Bruck D, Petersen K, Berman J. 2011. Stress alters rates and types of loss of heterozygosity in Candida albicans. MBio 2: 00129-00111.

Fridkin SK, Kaufman D, Edwards JR, Shetty S, Horan T. 2006. Changing incidence of Candida bloodstream infections among NICU patients in the United States: 1995 2004. Pediatrics 117: 1680-1687.

Gabaldon T, Martin T, Marcet-Houben M, Durrens P, Bolotin-Fukuhara M, Lespinet O, Arnaise S, Boisnard S, Aguileta G, Atanasova R, et al. 2013. Comparative genomics of emerging pathogens in the Candida glabrata clade. BMC Genomics 14: 623 .

Garcia-Effron G, Katiyar SK, Park S, Edlind TD, Perlin DS 2008. A naturally-occurring Fks1p Proline to Alanine amino acid change in Candida parapsilosis, Candida orthopsilosis and Candida metapsilosis accounts for reduced Echinocandin susceptibility. Antimicrob Agents Chemother 7: 2305-2312.

Garcia-Effron G, Lee S, Park S, Cleary JD, Perlin DS. 2009. Effect of Candida glabrata FKS1 and FKS2 mutations on echinocandin sensitivity and kinetics of $1,3-\beta$-D-glucan synthase: Implication for the existing susceptibility breakpoint. Antimicrob Agents Chemother 53: 36903699.

Geiger J, Wessels D, Lockhart SR, Soll DR. 2004. Release of a potent polymorphonuclear leukocyte chemoattractant is regulated by white-opaque switching in Candida albicans. Infect Immun 72: 667-677.
Gilfillan GD, Sullivan DJ, Haynes K, Parkinson T, Coleman DC, Gow NA. 1998. Candida dubliniensis: Phylogeny and putative virulence factors. Microbiology 144: 829-838.

Gomes AC, Miranda I, Silva RM, Moura GR, Thomas B, Akoulitchev A, Santos MA. 2007. A genetic code alteration generates a proteome of high diversity in the human pathogen Candida albicans. Genome Biol 8: pR206.

Grumaz C, Lorenz S, Stevens P, Lindemann E, Schock U, Retey J, Rupp S, Sohn K. 2013. Species and condition specific adaptation of the transcriptional landscapes in Candida albicans and Candida dubliniensis. BMC Genomics 14: 212.

Guida A, Lindstadt C, Maguire SL, Ding C, Higgins DG, Corton NJ, Berriman M, Butler G. 2011. Using RNAseq to determine the transcriptional landscape and the hypoxic response of the pathogenic yeast Candida parapsilosis. BMC Genomics 12: 628.

Hadfield TL, Smith MB, Winn RE, Rinaldi MG, Guerra C. 1987. Mycoses caused by Candida lusitaniae. Rev Infect Dis 9: 1006-1012.

Hawkins JL, Baddour LM. 2003. Candida lusitaniae infections in the era of fluconazole availability. Clin Infect Dis 36: e14-e18.

Heitman J. 2010. Evolution of eukaryotic microbial pathogens via covert sexual reproduction. Cell Host Microbe 8: 86-99.

Hernday AD, Lohse MB, Fordyce PM, Nobile CJ, Derisi JL, Johnson AD. 2013. Structure of the transcriptional network controlling white-opaque switching in Candida albicans. Mol Microbiol 90: 22-35.

Hickman MA, Zeng G, Forche A, Hirakawa MP, Abbey D, Harrison BD, Wang YM, Su CH, Bennett RJ, Wang Y, et al. 2013. The "obligate diploid" Candida albicans forms mating-competent haploids. Nature 494: 55-59.

Hill JA, Ammar R, Torti D, Nislow C, Cowen LE. 2013. Genetic and genomic architecture of the evolution of resistance to antifungal drug combinations. PLoS Genet 9: $\mathrm{e} 1003390$.

Hoyer LL. 2001. The ALS gene family of Candida albicans. Trends Microbiol 9: 176-180.

Hoyer LL, Green CB, Oh SH, Zhao X. 2008. Discovering the secrets of the Candida albicans agglutinin-like sequence (ALS) gene family-A sticky pursuit. Med Mycol 46: $1-15$.

Huang G. 2012. Regulation of phenotypic transitions in the fungal pathogen Candida albicans. Virulence 3: 251-261.

Huang G, Wang H, Chou S, Nie X, Chen J, Liu H. 2006. Bistable expression of WOR 1 , a master regulator of whiteopaque switching in Candida albicans. Proc Natl Acad Sci 103: $12813-12818$.

Huang M, McClellan M, Berman J, Kao KC. 2011. Evolutionary dynamics of Candida albicans during in vitro evolution. Eukaryot Cell 10: 1413-1421.

Ibrahim AS, Luo G, Gebremariam T, Lee H, Schmidt CS, Hennessey JP Jr, French SW, Yeaman MR, Filler SG, Edwards JE Jr. 2013. NDV-3 protects mice from vulvovaginal candidiasis through $\mathrm{T}$ - and B-cell immune response. Vaccine 31: 5549-5556.

Jackson AP, Gamble JA, Yeomans T, Moran GP, Saunders D, Harris D, Aslett M, Barrell JF, Butler G, Citiulo F, et al. 2009. Comparative genomics of the fungal pathogens 
S.A. Turner and G. Butler

Candida dubliniensis and C. albicans. Genome Res 19: 2231-2244.

Jacobsen ID, Wilson D, Wachtler B, Brunke S, Naglik JR, Hube B. 2012. Candida albicans dimorphism as a therapeutic target. Expert Rev Anti Infect Ther 10: 85-93.

Jones T, Federspiel NA, Chibana H, Dungan J, Kalman S, Magee BB, Newport G, Thorstenson YR, Agabian N, Magee PT, et al. 2004. The diploid genome sequence of Candida albicans. Proc Natl Acad Sci 11: 7329-7334.

Kaur R, Ma B, Cormack BP. 2007. A family of glycosylphosphatidylinositol-linked aspartyl proteases is required for virulence of Candida glabrata. Proc Natl Acad Sci 104: $7628-7633$.

Kempf M, Cottin J, Licznar P, Lefrancois C, Robert R, Apaire-Marchais V. 2009. Disruption of the GPI protein-encoding gene IFF4 of Candida albicans results in decreased adherence and virulence. Mycopathologia 168: $73-77$.

Kim SK, El Bissati K, Ben Mamoun C. 2006. Amino acids mediate colony and cell differentiation in the fungal pathogen Candida parapsilosis. Microbiology 152: 2885-2894.

Klevay MJ, Ernst EJ, Hollanbaugh JL, Miller JG, Pfaller MA, Diekema DJ. 2008. Therapy and outcome of Candida glabrata versus Candida albicans bloodstream infection. Diagn Microbiol Infect Dis 60: 273-277.

Kurtzman CP, Fell JW, Boekhout T. 2011. The Yeasts, a Taxonomic Study. Elsevier, Amsterdam.

Kvaal CA, Srikantha T, Soll DR. 1997. Misexpression of the white-phase-specific gene WH11 in the opaque phase of Candida albicans affects switching and virulence. Infect Immun 65: 4468-4475.

Kvaal C, Lachke SA, Srikantha T, Daniels K, McCoy J, Soll DR. 1999. Misexpression of the opaque-phase-specific gene PEP1 (SAP1) in the white phase of Candida albicans confers increased virulence in a mouse model of cutaneous infection. Infect Immun 67: 6652-6662.

L'Ollivier C, Labruere C, Jebrane A, Bougnoux ME, d'Enfert C, Bonnin A, Dalle F. 2012. Using a multi-locus microsatellite typing method improved phylogenetic distribution of Candida albicans isolates but failed to demonstrate association of some genotype with the commensal or clinical origin of the isolates. Infect Genet Evol 12: 1949-1957.

Lackey E, Vipulanandan G, Childers DS, Kadosh D. 2013. Comparative evolution of morphological regulatory functions in Candida species. Eukaryot Cell 12: $1356-$ 1368.

Laffey SF, Butler G. 2005. Phenotype switching affects biofilm formation by Candida parapsilosis. Microbiology 151: 1073-1081.

Lane MM, Burke N, Karreman R, Wolfe KH, O'Byrne CP, Morrissey JP. 2011. Physiological and metabolic diversity in the yeast Kluyveromyces marxianus. Antonie Van Leeuwenhoek 100: 507-519.

Lee I, Fishman NO, Zaoutis TE, Morales KH, Weiner MG, Synnestvedt M, Nachamkin I, Lautenbach E. 2009. Risk factors for fluconazole-resistant Candida glabrata bloodstream infections. Arch Intern Med 169: 379-383.

Li L, Redding S, Dongari-Bagtzoglou A. 2007. Candida glabrata: An emerging oral opportunistic pathogen. J Dent Res 86: 204-215.
Liu H. 2001. Transcriptional control of dimorphism in Candida albicans. Curr Opin Microbiol 4: 728-735.

Liu H. 2002. Co-regulation of pathogenesis with dimorphism and phenotypic switching in Candida albicans, a commensal and a pathogen. IJMM 292: 299-311.

Lockhart SR, Joly S, Vargas K, Swails-Wenger J, Enger L, Soll DR. 1999. Natural defenses against Candida colonization breakdown in the oral cavities of the elderly. J Dent Res 78: 857-868.

Lockhart SR, Messer SA, Gherna M, Bishop JA, Merz WG, Pfaller MA, Diekema DJ. 2009. Identification of Candida nivariensis and Candida bracarensis in a large global collection of Candida glabrata isolates: Comparison to the literature. J Clin Microbiol 47: 1216-1217.

Lohse MB, Johnson AD. 2009. White-opaque switching in Candida albicans. Curr Opin Microbiol 12: 650-654.

Lott TJ, Kuykendall RJ, Welbel SF, Pramanik A, Lasker BA. 1993. Genomic heterogeneity in the yeast Candida parapsilosis. Curr Genet 23: 463-467.

MacCallum DM, Castillo L, Nather K, Munro CA, Brown AJ, Gow NA, Odds FC. 2009. Property differences among the four major Candida albicans strain clades. Eukaryot Cell 8: $373-387$.

Maguire SL, Oheigeartaigh SS, Byrne KP, Schroder MS, O'Gaora P, Wolfe KH, Butler G. 2013. Comparative genome analysis and gene finding in Candida species using CGOB. Mol Biol Evol 30: 1281-1291.

Merz WG. 1984. Candida lusitaniae: Frequency of recovery, colonization, infection, and amphotericin B resistance. J Clin Microbiol 20: 1194-1195.

Miranda I, Silva-Dias A, Rocha R, Teixeira-Santos R, Coelho C, Goncalves T, Santos MA, Pina-Vaz C, Solis NV, Filler SG, et al. 2013. Candida albicans CUG mistranslation is a mechanism to create cell surface variation. MBio 4.

Mitrovich QM, Tuch BB, Guthrie C, Johnson AD. 2007. Computational and experimental approaches double the number of known introns in the pathogenic yeast Candida albicans. Genome Res 17: 492-502.

Moran GP, MacCallum DM, Spiering MJ, Coleman DC, Sullivan DJ. 2007. Differential regulation of the transcriptional repressor NRG1 accounts for altered host-cell interactions in Candida albicans and Candida dubliniensis. Mol Microbiol 66: 915-929.

Moreno-Ruiz E, Galan-Diez M, Zhu W, Fernandez-Ruiz E, d'Enfert C, Filler SG, Cossart P, Veiga E. 2009. Candida albicans internalization by host cells is mediated by a clathrin-dependent mechanism. Cell Microbiol 11: 11791189.

Morschhauser J. 2010. Regulation of white-opaque switching in Candida albicans. Med Microbiol Immunol 199: $165-172$.

Munoz P, Sanchez-Somolinos M, Alcala L, RodriguezCreixems M, Pelaez T, Bouza E. 2005. Candida krusei fungaemia: Antifungal susceptibility and clinical presentation of an uncommon entity during 15 years in a single general hospital. J Antimicrob Chemother 55: 188-193.

Muzzey D, Schwartz K, Weissman JS, Sherlock G. 2013. Assembly of a phased diploid Candida albicans genome facilitates allele-specific measurements and provides a simple model for repeat and indel structure. Genome Biol 14: pR97. 
Negri M, Silva S, Henriques M, Oliveira R. 2012. Insights into Candida tropicalis nosocomial infections and virulence factors. Eur J Clin Microbiol Infect Dis 31: 13991412.

Nemeth T, Toth A, Szenzenstein J, Horvath P, Nosanchuk JD, Grozer Z, Toth R, Papp C, Hamari Z, Vagvolgyi C, et al. 2013. Characterization of virulence properties in the C. parapsilosis Sensu Lato species. PLoS ONE 8: e68704.

Nielsen K, Heitman J. 2007. Sex and virulence of human pathogenic fungi. Adv Genet 57: 143-173.

Nobile CJ, Mitchell AP. 2005. Regulation of cell-surface genes and biofilm formation by the C. albicans transcription factor Bcrlp. Curr Biol 15: 1150-1155.

Nobile CJ, Andes DR, Nett JE, Smith FJ, Yue F, Phan QT, Edwards JE, Filler SG, Mitchell AP. 2006. Critical role of Bcr1-dependent adhesins in C. albicans biofilm formation in vitro and in vivo. PLoS Pathog 2: e63.

Noble SM, French S, Kohn LA, Chen V, Johnson AD. 2010. Systematic screens of a Candida albicans homozygous deletion library decouple morphogenetic switching and pathogenicity. Nat Genet 42: 590-598.

Nobile CJ, Fox EP, Nett JE, Sorrells TR, Mitrovich QM, Hernday AD, Tuch BB, Andes DR, Johnson AD. 2012. A recently evolved transcriptional network controls biofilm development in Candida albicans. Cell 148: 126138.

O'Connor L, Caplice N, Coleman DC, Sullivan DJ, Moran GP. 2010. Differential filamentation of Candida albicans and Candida dubliniensis is governed by nutrient regulation of UME6 expression. Eukaryot Cell 9: 1383-1397.

Odds FC. 2009. In Candida albicans, resistance to flucytosine and terbinafine is linked to MAT locus homozygosity and multilocus sequence typing clade 1. FEMS Yeast Res 9: 1091-1101.

Odds FC. 2010. Molecular phylogenetics and epidemiology of Candida albicans. Future Microbiol 5: 67-79.

Odds FC, Bougnoux ME, Shaw DJ, Bain JM, Davidson AD, Diogo D, Jacobsen MD, Lecomte M, Li SY, Tavanti A, et al. 2007. Molecular phylogenetics of Candida albicans. Eukaryot Cell 6: 1041-1052.

Palige K, Linde J, Martin R, Bottcher B, Citiulo F, Sullivan DJ, Weber J, Staib C, Rupp S, Hube B, et al. 2013. Global transcriptome sequencing identifies chlamydospore specific markers in Candida albicans and Candida dubliniensis. PLoS ONE 8: e61940.

Pammi M, Holland L, Butler G, Gacser A, Bliss JM. 2013. Candida parapsilosis is a significant neonatal pathogen: A systematic review and meta-analysis. Pediatr Infect Dis $J$ 32: e206-216.

Panackal AA, Gribskov JL, Staab JF, Kirby KA, Rinaldi M, Marr KA. 2006. Clinical significance of azole antifungal drug cross-resistance in Candida glabrata. J Clin Microbiol 44: $1740-1743$.

Pande K, Chen C, Noble SM. 2013. Passage through the mammalian gut triggers a phenotypic switch that promotes Candida albicans commensalism. Nat Genet 45: 1088-1091.

Papon N, Courdavault V, Clastre M, Simkin AJ, Creche J, Giglioli-Guivarc'h N. 2012. Deus ex Candida genetics: Overcoming the hurdles for the development of a molec- ular toolbox in the CTG clade. Microbiology 158: 585600.

Papon N, Courdavault V, Clastre M, Bennett RJ. 2013a. Emerging and emerged pathogenic Candida species: Beyond the Candida albicans paradigm. PLoS Pathog 9: e10033550.

Papon N, Savini V, Lanoue A, Simkin AJ, Creche J, GiglioliGuivarc'h N, Clastre M, Courdavault V, Sibirny AA. 2013b. Candida guilliermondii: Biotechnological applications, perspectives for biological control, emerging clinical importance and recent advances in genetics. Curr Genet 59: 73-90.

Perepnikhatka V, Fischer FJ, Niimi M, Baker RA, Cannon RD, Wang YK, Sherman F, Rustchenko E. 1999. Specific chromosome alterations in fluconazole-resistant mutants of Candida albicans. J Bacteriol 181: 4041-4049.

Perez JC, Kumamoto CA, Johnson AD. 2013. Candida albicans commensalism and pathogenicity are intertwined traits directed by a tightly knit transcriptional regulatory circuit. PLoS Biol 11: e1001510.

Pfaller MA, Diekema DJ. 2004. Twelve years of fluconazole in clinical practice: Global trends in species distribution and fluconazole susceptibility of bloodstream isolates of Candida. Clin Microbiol Infect 10: 11-23.

Pfaller MA, Diekema DJ. 2007. Epidemiology of invasive candidiasis: A persistent public health problem. Clin $\mathrm{Mi}$ crobiol Rev 20: 133-163.

Pfaller MA, Diekema DJ, Jones RN, Sader HS, Fluit AC, Hollis RJ, Messer SA. 2001. International surveillance of bloodstream infections due to Candida species: Frequency of occurrence and in vitro susceptibilities to fluconazole, ravuconazole, and voriconazole of isolates collected from 1997 through 1999 in the SENTRY antimicrobial surveillance program. J Clin Microbiol 39: 3254-3259.

Pfaller MA, Diekema DJ, Jones RN, Messer SA, Hollis RJ. 2002. Trends in antifungal susceptibility of Candida spp. isolated from pediatric and adult patients with bloodstream infections: SENTRY Antimicrobial Surveillance Program, 1997 to 2000. J Clin Microbiol 40: 852-856.

Pfaller MA, Diekema DJ, Gibbs DL, Newell VA, Ng KP, Colombo A, Finquelievich J, Barnes R, Wadula J. 2008. Geographic and temporal trends in the isolation and antifungal susceptibility of Candida parapsilosis: A global assessment from the ARTEMIS DISK Antifungal Surveillance Program, 2001-2005. J Clin Microbiol.

Pfaller MA, Castanheira M, Messer SA, Moet GJ, Jones RN. 2010a. Variation in Candida spp. distribution and antifungal resistance rates among bloodstream infection isolates by patient age: Report from the SENTRY Antimicrobial Surveillance Program (2008-2009). Diagn Microbiol Infect Dis 68: 278-283.

Pfaller MA, Diekema DJ, Gibbs DL, Newell VA, Ellis D, Tullio V, Rodloff A, Fu W, Ling TA. 2010b. Results from the ARTEMIS DISK Global Antifungal Surveillance Study, 1997 to 2007: A 10.5-year analysis of susceptibilities of Candida species to fluconazole and voriconazole as determined by CLSI standardized disk diffusion. J Clin Microbiol 48: 1366-1377.

Pfaller MA, Moet GJ, Messer SA, Jones RN, Castanheira M. 2010c. Candida bloodstream infections: Comparison of species distributions and antifungal resistance patterns in 
S.A. Turner and G. Butler

community-onset and nosocomial isolates in the SENTRY Antimicrobial Surveillance Program, 2008-2009. Antimicrob Agents Chemother 55: 561-566.

Pfaller MA, Moet GJ, Messer SA, Jones RN, Castanheira M. 2010d. Geographic variations in species distribution and echinocandin and azole antifungal resistance rates among Candida bloodstream infection isolates: Report from the SENTRY Antimicrobial Surveillance Program (2008 to 2009). J Clin Microbiol 49: 396-399.

Pfaller MA, Moet GJ, Messer SA, Jones RN, Castanheira M. 2011a. Candida bloodstream infections: Comparison of species distributions and antifungal resistance patterns in community-onset and nosocomial isolates in the SENTRY Antimicrobial Surveillance Program, 2008-2009. Antimicrob Agents Chemother 55: 561-566.

Pfaller MA, Moet GJ, Messer SA, Jones RN, Castanheira M. 2011b. Geographic variations in species distribution and echinocandin and azole antifungal resistance rates among Candida bloodstream infection isolates: Report from the SENTRY Antimicrobial Surveillance Program (2008 to 2009). J Clin Microbiol 49: 396-399.

Phan QT, Myers CL, Fu Y, Sheppard DC, Yeaman MR, Welch WH, Ibrahim AS, Edwards JE Jr, Filler SG. 2007. Als3 is a Candida albicans invasin that binds to cadherins and induces endocytosis by host cells. PLoS Biol 5: e64.

Porman AM, Alby K, Hirakawa MP, Bennett RJ. 2011. Discovery of a phenotypic switch regulating sexual mating in the opportunistic fungal pathogen Candida tropicalis. Proc Natl Acad Sci 108: 21158-21163.

Porman AM, Hirakawa MP, Jones SK, Wang N, Bennett RJ. 2013. MTL-independent phenotypic switching in Candida tropicalis and a dual role for Wor1 in regulating switching and filamentation. PLoS Genet 9: e1003369.

Reedy JL, Floyd AM, Heitman J. 2009. Mechanistic plasticity of sexual reproduction and meiosis in the Candida pathogenic species complex. Curr Biol 19: 891-899.

Riccombeni A, Vidanes G, Proux-Wera E, Wolfe KH, Butler G. 2012. Sequence and analysis of the genome of the pathogenic yeast Candida orthopsilosis. PLoS ONE 7: e35750.

Rocha R, Pereira PJ, Santos MA, Macedo-Ribeiro S. 2011. Unveiling the structural basis for translational ambiguity tolerance in a human fungal pathogen. Proc Natl Acad Sci 108: 14091-14096.

Sai S, Holland L, McGee CF, Lynch DB, Butler G. 2011. Evolution of mating within the Candida parapsilosis species group. Eukaryot Cell 10: 578-587.

Santos MA, Keith G, Tuite MF. 1993. Non-standard translational events in Candida albicans mediated by an unusual seryl-tRNA with a $5^{\prime}$-CAG-3' (leucine) anticodon. $E M B O J 12$.

Sasse C, Hasenberg M, Weyler M, Gunzer M, Morschhauser J. 2013. White-opaque switching of Candida albicans allows immune evasion in an environment-dependent fashion. Eukaryot Cell 12: 50-58.

Savini V, Catavitello C, Onofrillo D, Masciarelli G, Astolfi D, Balbinot A, Febbo F, D'Amario C, D'Antonio D. 2011. What do we know about Candida guilliermondii? A voyage throughout past and current literature about this emerging yeast. Mycoses 54: 434-441.

Schillig R, Morschhauser J. 2013. Analysis of a fungus-specific transcription factor family, the Candida albicans zinc cluster proteins, by artificial activation. Mol Microbiol 89: 1003-1017.

Schmid J, Herd S, Hunter PR, Cannon RD, Yasin MS, Samad S, Carr M, Parr D, McKinney W, Schousboe M, et al. 1999. Evidence for a general-purpose genotype in Candida albicans, highly prevalent in multiple geographical regions, patient types and types of infection. Microbiology 145: 2405-2413.

Seervai RN, Jones SK Jr, Hirakawa MP, Porman AM, Bennett RJ. 2013. Parasexuality and ploidy change in Candida tropicalis. Eukaryot Cell.

Sellam A, Hogues H, Askew C, Tebbji F, van Het Hoog M, Lavoie H, Kumamoto CA, Whiteway M, Nantel A. 2010. Experimental annotation of the human pathogen Candida albicans coding and noncoding transcribed regions using high-resolution tiling arrays. Genome Biol 11: pR71.

Selmecki AM, Dulmage K, Cowen LE, Anderson JB, Berman J. 2009. Acquisition of aneuploidy provides increased fitness during the evolution of antifungal drug resistance. PLoS Genet 5: e1000705.

Selmecki A, Forche A, Berman J. 2010. Genomic plasticity of the human fungal pathogen Candida albicans. Eukaryot Cell 9: 991-1008.

Sherwood RK, Bennett RJ. 2009. Fungal meiosis and parasexual reproduction-Lessons from pathogenic yeast. Curr Opin Microbiol 12: 599-607.

Si H, Hernday AD, Hirakawa MP, Johnson AD, Bennett RJ. 2013. Candida albicans white and opaque cells undergo distinct programs of filamentous growth. PLoS Pathog 9: e1003210.

Silva RM, Paredes JA, Moura GR, Manadas B, Lima-Costa T, Rocha R, Miranda I, Gomes AC, Koerkamp MJ, Perrot M, et al. 2007. Critical roles for a genetic code alteration in the evolution of the genus Candida. EMBO J 26: $4555-$ 4565.

Silva S, Negri M, Henriques M, Oliveira R, Williams DW, Azeredo J. 2012. Candida glabrata, Candida parapsilosis and Candida tropicalis: Biology, epidemiology, pathogenicity and antifungal resistance. FEMS Microbiol Rev 36: 288-305.

Soll DR. 2000. The ins and outs of DNA fingerprinting the infectious fungi. Clin Microbiol Rev 13: 332-370.

Spellberg BJ, Ibrahim AS, Avanesian V, Fu Y, Myers C, Phan QT, Filler SG, Yeaman MR, Edwards JE Jr. 2006. Efficacy of the anti-Candida rAls3p-N or rAls1p-N vaccines against disseminated and mucosal candidiasis. J Infect Dis 194: 256-260.

Spellberg B, Ibrahim AS, Yeaman MR, Lin L, Fu Y, Avanesian V, Bayer AS, Filler SG, Lipke P, Otoo H, et al. 2008. The antifungal vaccine derived from the recombinant $\mathrm{N}$ terminus of Als3p protects mice against the bacterium Staphylococcus aureus. Infect Immun 76: 4574-4580.

Spiering MJ, Moran GP, Chauvel M, Maccallum DM, Higgins J, Hokamp K, Yeomans T, d'Enfert C, Coleman DC, Sullivan DJ. 2010. Comparative transcript profiling of Candida albicans and Candida dubliniensis identifies SFL2, a C. albicans gene required for virulence in a reconstituted epithelial infection model. Eukaryot Cell 9: 251-265.

Srikantha T, Borneman AR, Daniels KJ, Pujol C, Wu W, Seringhaus MR, Gerstein M, Yi S, Snyder M, Soll DR. 
The Candida Pathogenic Species Complex

2006. TOS9 regulates white-opaque switching in Candida albicans. Eukaryot Cell 5: 1674-1687.

Staib P, Morschhauser J. 2007. Chlamydospore formation in Candida albicans and Candida dubliniensis-An enigmatic developmental programme. Mycoses 50: 1-12.

Stokes C, Moran GP, Spiering MJ, Cole GT, Coleman DC, Sullivan DJ. 2007. Lower filamentation rates of Candida dubliniensis contribute to its lower virulence in comparison with Candida albicans. Fungal Genet Biol 44: $920-$ 931.

Sullivan DJ, Westerneng TJ, Haynes KA, Bennett DE, Coleman DC. 1995. Candida dubliniensis sp. nov.: Phenotypic and molecular characterization of a novel species associated with oral candidosis in HIV-infected individuals. Microbiology 141: 1507-1521.

Suzuki T, Ueda T, Watanabe K. 1997. The 'polysemous' codon-A codon with multiple amino acid assignment caused by dual specificity of tRNA identity. EMBO J 16: $1122-1134$.

Tavanti A, Davidson AD, Gow NA, Maiden MC, Odds FC. 2005. Candida orthopsilosis and Candida metapsilosis spp. nov. to replace Candida parapsilosis Groups II and III. J Clin Microbiol 43: 284-292.

Thompson DS, Carlisle PL, Kadosh D. 2011. Coevolution of morphology and virulence in Candida species. Eukaryot Cell 10: 1173-1182.

Trofa D, Soghier L, Long C, Nosanchuk JD, Gacser A, Goldman DL. 2011. A rat model of neonatal candidiasis demonstrates the importance of lipases as virulence factors for Candida albicans and Candida parapsilosis. Mycopathologia 172: 169-178.

Tsai HF, Krol AA, Sarti KE, Bennett JE. 2006. Candida glabrata $P D R 1$, a transcriptional regulator of a pleiotropic drug resistance network, mediates azole resistance in clinical isolates and petite mutants. Antimicrob Agents Chemother 50: 1384-1392.

Tuch BB, Mitrovich QM, Homann OR, Hernday AD, Monighetti CK, De La Vega FM, Johnson AD. 2010. The transcriptomes of two heritable cell types illuminate the circuit governing their differentiation. PLoS Genet 6: e1001070.

Vale-Silva L, Ischer F, Leibundgut-Landmann S, Sanglard D. 2013. Gain-of-function mutations in PDR1, a regulator of antifungal drug resistance in Candida glabrata, control adherence to host cells. Infect Immun 81: 1709-1720.

van der Walt JP, Taylor MB, Liebenberg NV. 1977. Ploidy, ascus formation and recombination in Torulaspora (Debaryomyces) hansenii. Antonie Van Leeuwenhoek 43: 205218.

van het Hoog M, Rast TJ, Martchenko M, Grindle S, Dignard D, Hogues H, Cuomo C, Berriman M, Scherer S, Magee BB, et al. 2007. Assembly of the Candida albicans genome into sixteen supercontigs aligned on the eight chromosomes. Genome Biol 8: R52.

Vermitsky JP, Edlind TD. 2004. Azole resistance in Candida glabrata: Coordinate upregulation of multidrug transporters and evidence for a Pdr1-like transcription factor. Antimicrob Agents Chemother 48: 3773-3781.
Vermitsky JP, Earhart KD, Smith WL, Homayouni R, Edlind TD, Rogers PD. 2006. Pdr1 regulates multidrug resistance in Candida glabrata: Gene disruption and genome-wide expression studies. Mol Microbiol 61: 704-722.

Wachtler B, Citiulo F, Jablonowski N, Forster S, Dalle F, Schaller M, Wilson D, Hube B. 2012. Candida albicansepithelial interactions: Dissecting the roles of active penetration, induced endocytosis and host factors on the infection process. PLoS ONE 7: e36952.

Wickerham LJ, Burton KA. 1954. A clarification of the relationship of Candida guilliermondii to other yeasts by a study of their mating types. J Bacteriol 68: 594-597.

Wong S, Fares MA, Zimmermann W, Butler G, Wolfe KH. 2003. Evidence from comparative genomics for a complete sexual cycle in the "asexual" pathogenic yeast Candida glabrata. Genome Biol 4: R10.

Xie J, Du H, Guan G, Tong Y, Kourkoumpetis TK, Zhang L, Bai FY, Huang G. 2012. $N$-acetylglucosamine induces white-to-opaque switching and mating in Candida tropicalis, providing new insights into adaptation and fungal sexual evolution. Eukaryot Cell 11: 773-782.

Xie J, Tao L, Nobile CJ, Tong Y, Guan G, Sun Y, Cao C, Hernday AD, Johnson AD, Zhang L, et al. 2013. Whiteopaque switching in natural MTLa/ $\alpha$ isolates of Candida albicans: Evolutionary implications for roles in host adaptation, pathogenesis, and sex. PLoS Biol 11: e1001525.

Young LY, Hull CM, Heitman J. 2003. Disruption of ergosterol biosynthesis confers resistance to amphotericin B in Candida lusitaniae. Antimicrob Agents Chemother 47: 2717-2724.

Zhang A, Petrov KO, Hyun ER, Liu Z, Gerber SA, Myers LC. 2012a. The Tlo proteins are stoichiometric components of Candida albicans mediator anchored via the Med3 subunit. Eukaryot Cell 11: 874-884.

Zhang J, Silao FG, Bigol UG, Bungay AA, Nicolas MG, Heitman J, Chen YL. 2012b. Calcineurin is required for pseudohyphal growth, virulence, and drug resistance in Candida lusitaniae. PLoS ONE 7: e44192.

Zhu W, Phan QT, Boontheung P, Solis NV, Loo JA, Filler SG. 2012. EGFR and HER2 receptor kinase signaling mediate epithelial cell invasion by Candida albicans during oropharyngeal infection. Proc Natl Acad Sci 109: 1419414199.

Znaidi S, Nesseir A, Chauvel M, Rossignol T, d'Enfert C. 2013. A comprehensive functional portrait of two heat shock factor-type transcriptional regulators involved in Candida albicans morphogenesis and virulence. PLoS Pathog 9: e1003519.

Zordan RE, Galgoczy DJ, Johnson AD. 2006. Epigenetic properties of white-opaque switching in Candida albicans are based on a self-sustaining transcriptional feedback loop. Proc Natl Acad Sci 103: 12807-12812.

Zordan RE, Miller MG, Galgoczy DJ, Tuch BB, Johnson AD. 2007. Interlocking transcriptional feedback loops control white-opaque switching in Candida albicans. PLoS Biol 5: e256. 


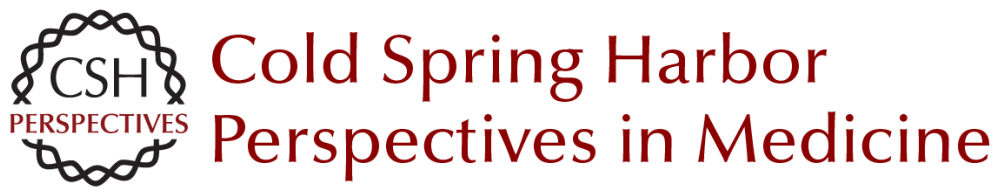

\section{The Candida Pathogenic Species Complex}

Siobhán A. Turner and Geraldine Butler

Cold Spring Harb Perspect Med 2014; doi: 10.1101/cshperspect.a019778

Subject Collection Human Fungal Pathogens

\section{Evolutionary Perspectives on Human Fungal Pathogens \\ John W. Taylor}
Black Molds and Melanized Yeasts Pathogenic to Humans Anuradha Chowdhary, John Perfect and G. Sybren de Hoog

Fungal Pathogens: Survival and Replication within Macrophages

Andrew S. Gilbert, Robert T. Wheeler and Robin C. May

Innate Defense against Fungal Pathogens

Rebecca A. Drummond, Sarah L. Gaffen, Amy G. Hise, et al.

Antifungal Pharmacokinetics and

Pharmacodynamics

Alexander J. Lepak and David R. Andes

Human Fungal Pathogens of Mucorales and

Entomophthorales

Leonel Mendoza, Raquel Vilela, Kerstin Voelz, et al.

Functional Profiling of Human Fungal Pathogen

Genomes

Alexi I. Goranov and Hiten D. Madhani

Aspergillus fumigatus and Related Species Janyce A. Sugui, Kyung J. Kwon-Chung, Praveen $R$. Juvvadi, et al.
Thermally Dimorphic Human Fungal Pathogens-Polyphyletic Pathogens with a Convergent

Pathogenicity Trait

Anita Sil and Alex Andrianopoulos

Mechanisms of Antifungal Drug Resistance Leah E. Cowen, Dominique Sanglard, Susan J. Howard, et al.

\section{Treatment Principles for Candida and Cryptococcus Laura C. Whitney and Tihana Bicanic}

The Human Mycobiome Patrick C. Seed

Treatment Principles for the Management of Mold Infections

Dimitrios P. Kontoyiannis and Russell E. Lewis

Adaptive Immunity to Fungi Akash Verma, Marcel Wüthrich, George Deepe, et al.

The Candida Pathogenic Species Complex Siobhán A. Turner and Geraldine Butler

\section{Fungal Morphogenesis} Xiaorong Lin, J. Andrew Alspaugh, Haoping Liu, et al.

For additional articles in this collection, see http://perspectivesinmedicine.cshlp.org/cgi/collection/ 